\title{
From Bildungsroman to Geschäftsroman: The Posthuman Neoliberal Novel
}

\author{
Bayan AlAmmouri ${ }^{a}$ \\ b.ammouri@ju.edu.jo \\ Faculty of Foreign Languages, The University of Jordan, \\ Amman, Jordan \\ Dina Salman \\ dina.salman@ju.edu.jo \\ Faculty of Foreign Languages, The University of Jordan, \\ Amman, Jordan
}

\begin{abstract}
The emergence of posthumanism and the proliferation of neoliberal rationality have not only changed the meaning of the word human, but also the status of the human. Technological autonomy overpowers and replaces human agency and the human becomes marginal and peripheral on a planetary scale; in the same manner that humans have lost control over the machine, they have also lost control over their agentic narrative on a global scale and on a literary one. And in the same way neoliberal commodification reduces humans to non-humans and transforms technology to a transcendent other that can transform and control the body, neoliberal posthumanism transformed the genre of the novel. The authors argue that the decentralization of the human, triggered by posthumanism, and the commodification of the genre of the novel, triggered by neoliberalism, transformed the most popular subgenre of the novel, the bildungsroman into a geschäftsroman. There is considerable evidence that indicates that many contemporary novels no longer focus on the growth of human beings, but rather on the growth of businesses, instead. This paper analyzes Mohsin Hamid's How to get Filthy Rich in Rising Asia (2013), arguing that it is a poignant example of a geschäftsroman, in which the human is decentralized and the growth of the city and the development of the economy become the narrative's nucleus.
\end{abstract}

Keywords: Neoliberalism; posthumanism; bildungsroman; geschäftsroman; novels

\section{INTRODUCTION}

Traditionally, in looking at the representation of the human in the literary history of the novel, a prominent subgenre, called the bildungsroman, stands out as one of the most dominant depictions of what it means to be human in this world. In this study, the authors argue that the intersection between neoliberalism and posthumanism has altered that depiction of the human in the bildungsroman, which in turn caused the emergence of a new subgenre that the authors call the geschäftsroman. This paper argues that neoliberalism (in alliance with posthumanism) is capable of prioritizing itself over the individual in a variety of ways. Just as we see neoliberalism play out in real world scenarios ${ }^{1}$, showing us how the value of the human is being measured, literature is capable of portraying the very same scenario aesthetically and theoretically, conspicuously in novels.

Neoliberalism and the novel, particularly the postmodern novel, are closely connected, because neoliberalism dehumanizes individuals and capitalizes on this very act, reducing the

\footnotetext{
${ }^{1}$ A noteworthy example is the recent interview with Croatian philosopher Srecko Horvat for DiEM25 TV in which Noam Chomsky argues that COVID-19 is a result of neoliberal policies.

${ }^{a}$ Main \& corresponding author
} 
agency of the human and erasing individuality in the process. On the other hand, the genre of the novel is invested in the individual, and thus neoliberalism transforms it, like all else, into a neoliberal tool. Neoliberalism, however, does not kill the novel, it rather helps renovate it. For example, Mathias Nilges in his paper, "Neoliberalism and the time of the novel," argues that "neoliberalism, far from utterly subsuming and deforming the novel, makes the novel's engagement with time and logic of immediacy important like never before and makes the time of neoliberalism a time for the novel indeed" $(2015$, p. 371). Thus, the neoliberal novel is not the death of the postmodern novel, but its transition "from a fictional life to a real existence... [m]ore accurately, the fictions of postmodernism of the sixties and seventies have become the reality of the neoliberal present" ("Fictions of Neoliberalism" 2017, p. 111). In other words, the novel anticipated the neoliberal turn that we are experiencing now, heralding in not only a neoliberal turn, but also a posthuman era.

Both neoliberalism and posthumanism have redefined the individual and in turn the literary depictions of the self. Neoliberalism is not only a political socio-economic policy, but also a "governing rationality" that commodifies and economizes private and public spheres alike (Brown 2015, p. 50). Furthermore, neoliberalism not only centers on the economic dimensions of a society, but it is also "intimately tied to the government of the individual, to a particular manner of living" under the guise of neoliberal life (Read 2006, p. 27). In this manner, "neoliberalism [became] what we are, a mode of existence defined by individual selfresponsibility, entrepreneurial action, and the maximization of human capital" (Huehls and Smith 2017, p. 9). The human is also reconfigured by this neoliberal rationality, as they are no longer simply 'homo politicus' but 'homo oeconomicus' (Brown 2015, p. 78). The homo oeconomicus is a market actor who is created and not born - a hyper-individual, a "responsible self-investor and self-provider," and a commodified human who understands the win and lose dialectic of the market space (Brown 2015, p. 84). The individual in a neoliberal world functions in a way where they are seen as "moral agents" able to govern themselves outside the confines of traditional government (Peters 2016, p. 300). Posthumanism, accordingly, like "affect theory...cognitive theory, vibrant materialism, speculative realism, object-oriented ontology, thing theory, some versions of ecocriticism, some versions of digital humanities, and maybe medical humanities," is an offshoot of the neoliberal confederation (Song 2017, p. 52).

The most noteworthy common ground scheme between neoliberalism and posthumanism is the reconfiguration of the human. The essence of the human has changed from "complex interiorities" to plain "ciphers" (Mousley 2016, pp. 158-9). As maintained by Rosi Braidotti in The Post Human (2013), the meaning of the word human has changed insomuch that the human is no longer the center of the world (p. 37). The current posthuman condition displaces "the boundaries between the categories of the natural and the cultural" and these boundaries are now "blurred by the effects of scientific and technological advances," namely the neoliberal apparatus (Braidotti 2013, p. 3). Thus, posthumanism not only posits alternative views about "the human and the new formations of subjectivity," but it also brings "about the displacement of the human" (Braidotti, 2013, p. 38). This decentering, and displacement, has generated a condition of "panhumanity" - the interconnectedness between "the human and the non-human," namely, the post-anthropological turn (Braidotti 2013, 40/41). The whole process started when modern technologies blurred "the boundaries between the genders ... an egalitarian blurring of differences" (Braidotti, 2013, p. 109). All humans became the same: no race, no gender, and no identity. The neoliberal rationality paved the way for the posthuman condition; "a different political economy of affects came into action; a colder sensibility entered our system, paving the road to the posthuman" (Braidotti, 2013, p. 109). Technology is a hegemonic neoliberal tool that ensures the decentralization of the human and the persistence of the neoliberal logic. "The commodification process itself reduces humans to the status of manufactured and hence profit-driven technologically mediated objects" 
(Braidotti 2013, p. 106). Because of the technological autonomy that is realized by the posthuman turn, robotics is no longer subservient to the human (Braidotti 2013, p. 43). Humans no longer have control of either their surroundings or themselves.

In other words, both neoliberalism and posthumanism have reconfigured and decentered the human. Technological autonomy overpowers and replaces human agency and the human becomes marginal and peripheral on a planetary scale. The authors in this study argue that in the same manner that humans have lost control over the machine, they have also lost control over the agentic narrative on a global scale and on a literary one. And in the same way neoliberal commodification reduces humans to non-humans and transforms technology to a transcendent other that can transform and control the body, neoliberal posthumanism transforms the genre of the novel; the focus of the narrative in various modern novels is no longer the human, but the market economy instead (Braidotti 2013, p. 107). Neoliberalism responsibilizes individuals and creates hyper-individualistic market actors, and posthumanism on the other hand decentralizes the human that the human becomes overpowered and marginalized, life's story is no longer their story. Therefore, even if neoliberalism, and its congruent offspring posthumanism, does not kill the novel, they are evidently reshaping the novel's form and content.

In the long history of the novel and its legacy, the bildungsroman remains one the most prominent forms that represents the human and what it means to be human in all its aspects. This form, developed by the end of the eighteenth-century, exemplifies and defines what it meant to be human in that century, examining the cycle of human life in all its transitions from youth to maturity. Thus, the important question that arises is: What happens to the bildungsroman when the human is decentered and the individualism that helped this fascinating genre rise to power is transfigured or reduced? The authors maintain that the posthuman turn, which coincides with the neoliberal condition, has helped generate a new type of bildungsroman that discusses the growth of a business instead of the growth of a human. This new formation of the novel, which follows and draws the growth of a business, instead of a human, is replacing the traditional sense of the eighteenth-century bildungsroman and is becoming, what the authors are calling, a geschäftsroman. To echo Nilges' argument that the genre of the novel anticipated the neoliberal turn in the fictions of the 1960s and the 1970s, the novel is now anticipating another turn in the real temporal sphere of upcoming decades, when contemporary fictions are focused on the growth of businesses rather than on the growth of individuals.

\section{THE POSTHUMAN NEOLIBERAL NOVEL: DEFINING THE GESCHÄFTSROMAN}

The geschäftsroman, is a new form of the bildungsroman. The extensive research around the form of the bildungsroman examines the ways that the form has branched out in various subgenres and altered the original concept of the bildungsroman. Some of these subsets include the modernist bildungsroman, the postmodernist bildungsroman, as well as the colonial and postcolonial bildungsroman. Moreover, the bildungsroman as a subgenre has its own "variations within its kind [as well] such as Entwickslungroman (novel of development), Erziehungsroman (novel of education), Kunstlerroman (development of the artist) and Zeitroman which blends the development of era in which the hero lives with his or her personal development" (Thamarana 2015, p. 22). In this manner, the bildungsroman has proven its persistence and ability to survive, but more importantly, it has proven its ability to adapt and shapeshift. What is yet more essential is that the definition of the bildungsroman exhibits the dominance of the protagonist to the genre. Karl Morgenstern argues that "We may call a novel a Bildungsroman first and foremost on account of its content, because it represents the development of the hero in its beginning and progress to a certain stage of completion" (2009, 
654-5). The emphasis in the previous definition is on the growth of the character - the maturation of the protagonist is the epicenter of the narrative plot and structure.

Along the same lines, Mikhail Bakhtin addresses the transformative power of the Bildungsroman in reflecting the temporal and historical moment and writes of the same relationship between the protagonist's life and the historical epoch that the protagonist lives in, but adds that the protagonist ushers in a new epoch in the world; "He emerges along with world and he reflects the historical emergence of the world itself. He is no longer within an epoch, but on the border between two epochs, at the transition point from one to the other" (1986, p. 23). If the heroes of the bildungsroman are a reflection of the world they emerge from, then the current neoliberal world we are living in has paved the way to a new kind of bildungsroman. Bakhtin's definition of the transformative power represents a bildungsroman for every epoch and age; and, therefore, the age of neoliberalism has offered a different representation of the bildungsroman than readers are used to. Moreover, what is championed in the posthuman neoliberal bildungsroman (the geschäftsroman) is not the human, as the world this new form is presenting is one that decenters the human. The socioeconomic and political changes of our modern times have displaced the bildungsroman's human protagonist and have replaced that protagonist with a neoliberal dominant force: capital.

The bildungsroman, then, is the by-product of capital. Market economy and capitalism helped the genre of the novel emerge, and, nowadays, late capitalism (neoliberalism) is reshaping it. Enrique Lima in "The Uneven Development of the Bildungsroman: D'Arcy McNickle and Native American Modernity" contends that "capitalist modernity" is what "gave birth to the Bildungsroman" but as a result of the uneven distribution of capital on a global scale, writers from non-European spaces "refunctionalized it to address their alternative modernities" (2011, p. 291). Returning to the origins of both capitalism and the bildungsroman, Franco Moretti argues in The Way of the World: The Bildungsroman in European Culture (2000) that the form of the Bildungsroman is a symbol of European modernity: "The Bildungsroman [is] the 'symbolic form' of modernity" (2000, p. 5). Two elements emerge together during modernity: capitalism and the bildungsroman. Moretti states that the bildungsroman was the byproduct of the beginning of the modern age, while Lima creates an important relationship between capitalism and the form of the bildungsroman that posthuman neoliberalism is currently reshaping.

The beginning of modernism shows another subset of the bildungsroman (the modernist bildungsroman) that contributes subtly to the development of the posthuman neoliberal novel. The modernist bildungsroman unfolding in the twentieth century not only caused a rupture in the genre of the novel, but also fractured the underlying principles of the bildungsroman. First, modernism arises as a reaction against the principles of nineteenth- century realism and narrative forms. Some of the modernist novels' most prominent characteristics were experimentation in the form of the genre, fragmentation, and inwardness into the self. Two apt examples of this experimentation in the form of the bildungsroman are James Joyce's novel $A$ Portrait of the Artist as a Young Man and Oscar Wilde's The Picture of Dorian Gray. Both novels represent a number of characteristics that redefine the bildungsroman such as the loss of an autonomous self, fragmentation, and a general push against the socialization of the self. As the twentieth century progressed, multiple variations of the novel cropped up illustrating the multiple possibilities of modernism, one of which was the transformation of the novel as a "truly planetary" form and giving birth to the "global novel" (Mazzoni 2017, p. 337). The bildungsroman has also been able to cement itself within the modernist period offering a different insight into the novel of formation. Morretti writes in his appendix of The Way of the World that the twentieth century, particularly at the end of World War I, saw a disintegration of the main principles of the traditional nineteenth century bildungsroman; "More precisely, perhaps, the war was the final act in a longer process - the cosmic coup de grâce to a genre 
that, at the turn of the century, was already doomed" (2000, pp. 229-300). The modernist bildungsroman becomes a fissure in triumph of the bildungsroman and its transformation of the self. The result of the modernist bildungsroman is a fragmentary self that fails to make sense of the world or to find itself in the world. Thus, the authors believe that there is a subtle connection between the modernist bildungsroman and this new form the authors call the geschäftsroman. The modernist bildungsroman paved the way for the deterioration of the self that posthuman neoliberalism utilizes to decenter that self completely.

Posthuman neoliberalism, thus, becomes another historical and temporal dimension that the bildungsroman is capable of adopting towards. In light of this study, the authors attempt to carve out a small niche in the larger examination of the form and the scholarship of the bildungsroman within neoliberal discourses called the posthuman neoliberal bildungsroman: the geschäftsroman. The geschäftsroman is a novel in which the human is marginal, disposable, and collateral. It is a novel that celebrates entrepreneurial enterprises but not the entrepreneurs themselves, because it is a narrative that promotes the neoliberal hyper-individualistic self. A self that lacks agency and is desolate and bare; the homo oeconomicus not only understands the fatality of familial relations and affectivities, but also understands the inevitable fatality of the human that is needed and sometimes required for the survival of capital ${ }^{2}$. The posthuman neoliberal turn, the same sociopolitical rationality that is currently championing economic survival and justifying the deaths of large numbers of people during the COVID-19 pandemic, displaced the bildungsroman's human protagonist and replaced that protagonist with agentive neoliberal tools: cities, businesses, and machines. Most importantly, a geschäftsroman is not written to entertain or promote empathy, but it is written to responsibilize characters and readers alike, through forcefully persuasive narration, in order to ensure the full eradication of homo mensura and the proliferation of human capital instead. The next section scrupulously examines Mohsin Hamid's How to Get Filthy Rich in Rising Asia (2013) as an example of a geschäftsroman.

\section{READING THE GESCHÄFTSROMAN IN HOW TO GET FILTHY RICH IN RISING ASIA}

The burgeoning scholarship on Mohsin Hamid's How to get Filthy Rich in Rising Asia (2013) focuses on themes of neoliberalism and globalization, as well as on the novel's form and metafictional qualities. For instance, Alex Gilvarry closely examines the novel's inventive style, stating that "Hamid is as much an inventive stylist as he is a gifted storyteller, and he's very interested in playing with the novel's form, or rather, renewing it" $(2013, \mathrm{p}$. 1). Moreover, several scholars have called the novel a bildungsroman by default suggesting that it embodies traditional elements of that genre. For example, Angelia Poon's 2017 article "Helping the novel: Neoliberalism, self- help, and the narrating of the self in Mohsin Hamid's How to Get Filthy Rich in Rising Asia" and Liliana Naydan's 2018 piece "Beyond economic globalization in Mohsin Hamid's How to Get Filthy Rich in Rising Asia: The false promise of self-help and possibilities through reading with a creative mind" both emphasize how the self-help technique of the novel contributes to the depiction of the neoliberal individual. On the other hand, Swaralipi Nandi in her study, "Narrative Ambiguity and the neoliberal bildungsroman in Aravind Adiga's The White Tiger" (2017), categorizes Hamid's novel as a neoliberal bildungsroman, stating that "the neoliberal bildungsroman [is] a narrative of neoliberal subject formation, normalizing the protagonist into the new capitalistic social order" and "charts the protagonist's initiation into, fusion with, and active participation in normative ideology of

\footnotetext{
${ }^{2}$ It is worth noting here that the concept of corporate individuality or "corporate personhood" emerged in the late 19th century when American courts assigned human rights to businesses. For further reading on this please see Lyman Johnson's 2011 study "Law and Legal Theory in the History of Corporate Responsibility: Corporate Personhood.”
} 
neoliberalism" (pp. 276-277). What these studies show is that there is a major emphasis in the scholarship that claims that the novel centers on the neoliberal individual, but none of the scholarship attempts at all to examine how the neoliberal individual is, in fact, decentered. This study, however, examines Hamid's novel differently in view of the neoliberal individual arguing that the individual in his/her idealistic form is decentered, as the novel is a geschäftsroman in which the growth of the city and the development of the economy become the narrative's nucleus.

Hamid's novel is a geschäftsroman in both form and content. In form, the novel comes across as a self-help book addressed to a reader who desires desperately to become wealthy in a quickly developing Asian city. It is a self-help book in which each chapter begins with an examination of the contradictions of the self-help genre in relation to the novel and to neoliberalism. Furthermore, these short introductions on the uses and purpose of the self-help genre have metafictional overtones on writing and the genre of the novel and allude, at times, to the decentering of the self in the contemporary novel. For instance, in chapter one, the author writes that "the idea of self in the land of self-help is a slippery one" (Hamid 2013, p. 3). In chapter two, the narrator comments on the purposes of fiction writing, especially the importance of the novel itself: "And what of the other novels, those which for reasons of plot or language of wisdom of frequent gratuitous and graphic sex you actually enjoy and read with delighted hunger? Surely those too are versions of self-help" (p. 19). Another prominent example is in chapter four titled "Avoid Idealists," where the author comments on how the self can become decentered in the world of ideals: "Surely ideals, transcending as they do puny humans and repositing meaning in vast abstract concepts instead, are by their very nature antiself? It follows therefore that any self-help book advocating allegiance to an ideal is likely to be a sham" (Hamid 2013, p. 57). What these examples show is how the author attempts at pushing the self into the foreground in a satirical and ironic manner since the book is in fact supposed to serve the self. Yet, the self is denied agency from the beginning of the narrative and it appears as though it is only a tool in a larger network of neoliberal policies, politics, and polemics. The question then becomes centered on why a self-help book would deny the self or the protagonist of the text its agency. This satirical approach that Hamid is following detracts attention away from the self towards the purpose of becoming "filthy rich" - a more focused attempt at emphasizing the homo-oeconomicus dimension of the self of human capital. The self becomes dehumanized when the text is keen on satirizing the focus of the self-help narrative, reducing the self and the traditional sense of the self as a "sham." The self that is represented in Hamid's novel is not of a fictional character, but it is the self of the addressed homo-economicus reader. More specifically, the self of the text is a reflection of the individual reader who appears to want the same thing as the unnamed protagonist of the text - that is to become "filthy rich."

Just as the narrative form and structure offer telling evidence of a different version of the bildungsroman, so too does the texts' content. More specifically, the decentralization of the human and the shift to focusing on the growth of a neoliberal entrepreneurial project; a filtered bottled-water business, which is a quintessential example of neoliberal ideals - making money out of basic human needs. The entrepreneurial project is "a small business, a workhorse $\mathrm{S}$ in the thunderous economic herd of what bankers and policy makers call SMEs. You operate out of a two-room rented accommodation you once shared with your father" (Hamid 2013, p. 98). Because he uses his own savings to buy a place to run his business, the narrative dubiously celebrates him as "a man who works for himself, an entrepreneur" (Hamid 2013, p. 114). What is worth noting here is that he gets the idea to build a filtered water business from the governmental and humanitarian negligence of populations that result in disastrous fatalities due to the consumption of highly contaminated water; 
Your city's neglected pipes are cracking, the contents of underground water mains and sewers mingling, with the result that taps in locales rich and poor alike disgorge liquids that, while for the most part clear and often odorless, reliably contain trace levels of feces and microorganisms capable of causing diarrhea, hepatitis, dysentery, and typhoid. Those less well-off among the citizenry harden their immune systems by drinking freely, sometimes suffering losses in the process, especially of their young and their frail.

(Hamid, 2013, p. 99)

The narrative does not responsibilize the state, nor does it responsibilize non-profit organizations, as that responsibilization shifted to the individual in the late twentieth century, when neoliberalism emerged as "a way of reordering social reality, and of rethinking our status as individuals" (Metcalf 2017, p. 2). "Disintegrating the social into entrepreneurial and selfinvesting bits removes umbrellas of protection provided by belonging, whether to a pension plan or to a citizenry" which causes the decentralization of the human in the neoliberal sphere (Brown 2015, p. 37). Hamid advocates violence, selfishness, and compassionless cruelty when the narrator declares that the "fruits of labor are delicious, but individually they're not particularly fattening. So don't share yours, and munch on those of others whenever you can" (2013, p. 98). The novel offers suggestions on "how to parlay 'your' natural talents into wealth amid a society of breathtaking ruthlessness and striving" and, at the same time, celebrates actions that epitomize neoliberal hyper-individualism (Miller 2013, p. 1). The novel's leitmotif shows how a prototypical individual, the 'you' of the story, is trying to secure a place in a growing economic machine, which aligns closely with the facade of the neoliberal bildungsroman. Nevertheless, there is always a hint of irony in the tone of the narrator in the way that he describes the water bottle business's early beginnings and in the dispensability of the human, such as those who "drink[] freely, sometimes suffering losses in the process, especially of their young and frail" (Hamid 2013, p. 99). There are individuals, such as the "you" character in the narrative, whose lives appear to have value and, yet, still must drink polluted water and risk their health.

As a consequence, Hamid's novel not only celebrates hyper-individual entrepreneurial enterprises, but also emphasizes the disposability of the human in the global market, not in a negative manner, but rather as an inevitability. Therefore, what makes How to Get Filthy Rich in Rising Asia a good example of a geschäftsroman is that it endorses labor as a survival rationality and, at the same time, accepts that humans are insignificant and that human loss is an acceptable casualty of a bigger, more important scheme: the posthuman neoliberal market. In the seventh chapter of the novel, Hamid proclaims, "[W]ealth comes from capital, and capital comes from labor, and labor comes from equilibrium, from calories in chasing calories out, an inherent, in-built leanness, the leanness of biological machines" (2013, p. 119). Humans are paralleled to machines; they become mechanical beings whose sole existence is linked to production, and in whom compassion and equality are obliterated. The "guarantee of equality through the rule of law and participation in popular sovereignty is replaced with a market formulation of winners and losers" (Brown 2015, p. 41). The logic of wealth prevails and frames "contestations over who we are, what we should be or become, what we should or should not do as a people. Democracies are conceived as requiring technically skilled human capital, not educated participants in public life and common rule" (Brown 2015, p. 177). This neoliberal reasoning leads to posthuman conclusions; "posthuman vital politics shifts the boundaries between life and death and consequently deals not only with the government of the living, but also with practices of dying" (Braidotti 2013, p. 111). Thus, human bodies "become the disposable bodies of the global economy. Contemporary capitalism is indeed 'bio-political' in that it aims at controlling all that lives" (Braidotti 2013, p. 111). The nameless male character's eldest brother in Hamid's narrative drops out of school and gets a job as a painter's assistant (2013, p. 28). Then, the brother's health deteriorates and he starts to cough, "the 
reason for his cough is paint inhalation" (Hamid 2013, p. 29). He works for minimum wages at the maximum number of hours. He is always "sweating in unventilated, infernally hot conditions... like a robot in an automotive assembly plant, but with slightly less precision" (p. 31). Hamid's deduction after a lengthy description of the awful working conditions of laborers, especially children, is that "the skills he learns are valuable, and in any case over sufficiently long a term, as everyone knows, there is nothing that does not have as its consequence death" (p. 32). Thus, a homo-oeconomicus needs to have capabilities to compete and survive in the global economy and also needs to understand that the inevitable outcome is always death.

The death of the human is rampant in the narrative, and yet the demise of characters is addressed only in passing to emphasize the noncentrality of the individual. When the mother dies " $[t]$ he speed of her progression from solid heartiness to ephemeral fragility has been so strange as to be almost fantastic. Rose petals are thrown, incense lit, entreaties to the divine offered, and then those of you still living return to your lives" (Hamid 2013, p. 72). The father's death is shrouded with ambivalence and not commented on: "You bring him a cup of water and sit beside him, and he pats your hand, his callused palm leathery and almost soft. He whispers a benediction and breathes it into the air, spreading his hopes for you with a contraction of the lungs" (Hamid 2013, p. 93). The sister's death is introduced as a disruptive incident as the nameless male character's life "routine is initially broken not by an act of violence but by the death of your sister" (Hamid 2013, p. 131). The nameless "you" character goes to his sister's funeral out of obligation and "[y]ou offer your prayers at the flower-strewn mound of earth that caps your sister's resting place, and you give the money you have brought to her husband and children. Death in the village, being common, is handled in a matter-of-fact manner" (Hamid 2013, p. 132). A gunman "you" hire lightheartedly murders a boyish motorcyclist; "[y] our guard fires several rounds into his face and chest and snaps a photo with his mobile phone" to send a message to a wealthy businessman and establish dominance in the market (Hamid 2013, p. 134). The brother dies and it is only mentioned in passing: "Your parents have died, your surviving sister and brother survive no longer, your wife has left you and married a man closer to herself in outlook and in age, and your son has chosen not to return after studying in North America" (Hamid 2013, p. 177). Even the description of the death of the love of his life is breezy: "When the pretty girl's death comes it is mercifully swift, at diagnosis her cancer having spread from her pancreas throughout her body... she spends her final weeks at home... She dies on a windy morning with her eyes open. You arrange to bury her at a graveyard belonging to her community" (Hamid 2013, pp. 219-220). And, at last, the novel ends with the death of "you" on a hospital bed welcoming and accepting death, the last sentence of the story is: "So may all of us confront the end" (Hamid 2013, p. 222). Accordingly, at many instances the description of death in this narrative is vague and minimal to the point that the reader is often not sure if a character died or not. This contributes to the social distancing required in posthuman neoliberal discourses between the readers and the characters in the text. It would seem like readers are not expected to feel sad, nor are they expected to empathize; the readers only understand and accept the modern reality of the posthuman neoliberal turn as the characters in the text do.

The death of characters in this novel explicates the decentralization of the human, and its parallelism with the birth and growth of the city, which is the quintessence of the growth of capital and wealth, centralizes posthuman neoliberal tools and technologies ${ }^{3}$. At the beginning of the narrative, the father contemplates nature and how similarly humans and plants develop (Hamid 2013, p. 5). The father also considers the death of nature, and thus the human, in light

\footnotetext{
${ }^{3}$ There are multiple modern studies that address the focal point technology plays in forming identity, especially youth identity. For example, "Postcolonial Civic Identity and Youth (dis)organizing Environment: A Growth into Citizenship Analysis" closely studies how "technology grants youth the opportunity to identify and link ecology to civic affairs" helping youth better understand their identity as citizens in a postcolonial context (Idrus 2020,139). Be that as it may, it is important to bear in mind that technology in neoliberal/posthuman contexts is a hegemonic tool that obliterates identity altogether.
} 
of global industrialization of life and its organisms (Hamid 2013, p. 5). "[O]n one of a thousand and one rutted streets where a few years ago were only fields but now little green can be seen, unplanned development having yielded instead a ribbon of convenience stores, auto garages, scrap-metal dealers, unregistered educational institutes, fly-by-night dental clinics, and mobilephone top-up and repair points" (Hamid 2013, 120). So, as people die, the city grows:

\begin{abstract}
Your city is enormous, home to more people than half the countries in the world, to whom every few weeks is added a population equivalent to that of a small, sandy-beached, tropical island republic, a population that arrives, however, not by outrigger canoe or lateen-sailed dhow but by foot and bicycle and scooter and bus. A limited-access ring road is under construction around the place, forming a belt past which its urban belly is already beginning to bulge, and from which ramps soar and arc off in every direction. Your bus barrels along in the shadow of these monuments, dusty new arteries feeding this city, which despite its immensity is only one among many such organs quivering in the torso of rising Asia.
\end{abstract}

(Hamid, 2013, p. 82)

The city in the previous excerpt is alive with arteries that help it grow to form the torso of a posthuman neoliberal Asia. This growing entity is atrocious and perilous to humans, because its development relies on consuming human capital. "Yes, the city remains intermittently perilous, in, for example, the slashing thrusts of its vehicles, the ferocious extremes of its temperatures, and the antibiotic resistance of its microorganisms, not to mention the forcefulness of its human predators" (Hamid 2013, p. 207). The city becomes a scavenger that feeds on the weak: "Frequently you have the impression of gazing with the pretty girl ... off into a valley where night is falling, a stark and dry and contaminated valley, where perhaps all sorts of bony, mutating creatures abide, many of them carnivorous," and "having had your share of carnivorous tendencies yourself, you know that carnivores feed especially on the old and the sick and the frail, terms that have come to cling ever more tightly to you, eroding what once was your supple skin" (Hamid 2013, p. 217). The city is scary to the weak, old, and frail, because in a jungle-like milieu survival is simply for the fittest. Humans are nothing more than mortal tools used to further neoliberal projects and help achieve the posthuman condition.

The growth of the city and the death of the human assist technologies' rise to dominance. Individuals are surveilled, as if subject to a panopticon, through "the machine's built-in camera and microphone to be activated and monitored remotely... transforming the laptop, in effect, into a covert surveillance device" (Hamid 2013, p. 169). Characters are also monitored through "unmanned aerial vehicle[s]... Its chief advantages are its low cost, allowing it to be procured in large numbers, and its comparative quietness, permitting it to function unobtrusively" (Hamid 2013, p. 173). The technological devices in the narrative include computers, planes, and drones; they not only aid in transforming agency from human to machine, but also aid into transfiguring the human into machines:

From the perspective of the world's national security apparatuses you exist in several locations. You appear on property and income-tax registries, on passport and ID card databases. You show up on passenger manifests and telephone logs. You hum inside electromagnetically shielded military intelligence servers and, deep below pristine fields and forbidding mountains, on their dedicated backups. You are fingertip swirls, facial ratios, dental records, voice patterns, spending trails, e-mail threads.

(Hamid 2013, p. 161)

And, thus, the human identity is digitalized and we become data:

WE'RE ALL INFORMATION, ALL OF US, WHETHER readers or writers, you or I. The DNA in our cells, the bioelectric currents in our nerves, the chemical emotions in our brains, the configurations of atoms within us and of subatomic particles within them, the galaxies and 
whirling constellations we perceive not only when looking outward but also when looking in, it's all, every last bit and byte of it, information.

(Hamid, 2013, p. 160)

Even if the human is incapable of understanding who/what they are, "[w] hat we do know is that information is power" (Hamid 2013, p. 160). The human is overpowered to the point that they are imbued into data and technology. The "digitization" and "datafication" of the self causes us to "perform our data," as "data about who we are becomes more important than who we really are" (Cheney-Lippold 2017, pp. 11-25). Computational data that is collected through neoliberal algorithms and technologies becomes a dominant agentive factor that replaces and decentralizes the human self. Through our heavy reliance and immersion in neoliberal technologies our "individuality" becomes a set of "dividualities" instead---separate, divided, and easily controlled bits of information that is maintained through "network power" (Cheney-Lippold 2017, p. 27).

In Hamid's narrative, technologies and computational data not only decentralize the human self but also consume that very self. When the eldest brother works day and night to make ends meet, he describes himself "like a robot in an automotive assembly plant" (2013, p. 31). And when "you" have a heart-attack, you "become a kind of cyborg, part man, part machine. Electrodes connect your chest to a beeping computer terminal mounted on a rack, and a pair of transparent tubes channel oxygen from a nearby metal tank to your nostrils and fluids from a plastic pouch into your bloodstream through a needle taped at your wrist" (Hamid 2013, p. 183). Then you "understand... that for the moment this apparatus and you are inseparable" (Hamid 2013, p. 183). The narrator also writes:

\begin{abstract}
"To be a man whose life requires being plugged into machines, multiple machines, in your case interfaces electrical, gaseous, and liquid, is to experience the shock of an unseen network suddenly made physical, as a fly experiences a cobweb. The inanimate strands that cling to your precariously still-animate form themselves connect to other strands, to the hospital's power system, its backup generator, its information technology infrastructure, the unit that produces oxygen, the people who refill and circulate tanks, the department that replenishes medications, the trucks that deliver them, the factories at which they are manufactured, the mines where requisite raw materials emerge, and on and on, from your body, into your room, across the building, and out the doors to the world beyond, mirroring in stark exterior reality preexisting and mercifully unconsidered systems within, the veins and nerves and sinews and lymph nodes which there is no you.
\end{abstract}

(Hamid, 2013, pp. 183-4)

Hamid here writes a particularly poignant representation of the erasure of the self in an obviously ruthless neoliberal world. When "you" is sent to the hospital and needs multiple machines to keep him going, he realizes that his life is clearly dependent on an exterior reality that has been structured from beginning to end by a neoliberal rationality ${ }^{5}$. Thus, the narrator of this geschäftsroman explains that there is no interior world within "you," only a body that is not even autonomous, as it is only alive via machines and an "unseen network." Moreover, the description of the system shows readers that the human is only functional within a "network" of businesses providing services to the hospital and "you" only become a speck of dust in this large chain.

\footnotetext{
${ }^{4}$ The anonymous collective pronoun used by Hamid in this novel brings to mind Albert Memmi's "anonymous collectivity" that "negated all the good attributes of the colonized to the extent that he was gradually deprived of both his humanity and individuality" (Mehrvand 2018, 35). Without a doubt, the posthuman neoliberal turn, like colonial forces, depersonalizes the human experience and groups individuals into disposable anonymous collective bodies.

${ }_{5}^{5}$ It is noteworthy to mention here that the representation of the hospital can be examined through Foucauldian theory, where the hospital becomes a tool that oppresses individuals, closely scrutinizes the human self, and is no longer a place of refuge. Hence, Moussa Pourta Asl and Nurul Farhana Low Abdullah write in their article "Circulation of the Discourse of American Nationalism through Allegiance to Consumer Citizenship in Jhumpa Lahiri's The Namesake", that "The hospital, in Foucauldian analysis, is not conceived as an instrument of cure, but rather it has signified a constant focal point of the economic and social order, a new form of governing and discipline that exacts a perpetual surveillance on individuals, whereby the individual turns into an object of knowledge and medical interventions" (2017, 58).
} 


\section{CONCLUSION}

In this study the authors argue that both posthumanism and neoliberalism reshape the genre of the novel, and, at the same time, they decentralize the individual protagonist of the bildungsroman to pave the way for a new agentive narrative nucleus---neoliberal capital. The authors maintain that these changes, on global and literary levels, have helped not only redefine the meaning of the word human, but they have also helped erase the status of the human on a planetary scale, resulting in a new narrative form: the geschäftsroman. This posthuman neoliberal novel does not center around a protagonist, rather, it promotes hyper individualism, celebrates the growth of neoliberal apparatuses, and accepts the inevitability of human death and humans' disposability in this late-capitalist economy. The authors argue that Mohsin Hamid's novel, How to Get Filthy Rich in Rising Asia, can be read as a geschäftsroman. Hamid makes use of the self-help genre to formally displace both characters and readers; and, at the same time, he weaves his narrative thread to focus on the growth of a city and of an entrepreneurial bottled-water business, rather than on a protagonist, which further decentralizes the self. Hamid appears to focus particularly on how this neoliberal world is unwilling to accept the self as one with agency, individualism, and selfhood. Instead, the self becomes subsumed into a powerful, late-capitalist machine. Hamid's self is no longer the celebrated self, which emerges during the $18^{\text {th }}$ century; this new self has been stripped of its characteristics to function in a global market.

There are other narratives that could be fully or partially approached as geschäftsromans. Frankissstein (2019) by Jeanette Winterson, for example, explores the possibility of transforming humanity into an abstract concept. The scientist (Victorstein) in the narrative aims at transfiguring himself into data to be able to survive in an AI form after his death. Victorstein's attempts to eliminate death not only acknowledge the disposability of human bodies in this technological age, but also acknowledge the power of the machine and the periphery status the human has gained in the posthuman neoliberal turn. Another example is The White Tiger (2008), by Aravind Adiga, an epistolary narrative that tells the story of Balram Halwai, who is a very poor villager determined on becoming rich at any cost. He ends up killing someone, stealing money, and resorting to corruption in order to establish his entrepreneurial taxi-services. Even though Balram does not die and does not lose his business at the end of the novel, this narrative can still be read as a geschäftsroman because Balram is represented as a posthuman, neoliberal, hyper-individual who distances himself from his family and who bribes and kills often to obtain money and power in a neoliberal realm, where capital has more agency and control than humans. Finally, A Young Man's Guide to Late Capitalism (2011) by Peter Mountford is also a novel that can be read as a geschäftsroman. It is a narrative that adopts the guidebook format for upper class young men in telling Gabriel Francisco de Boya's story. This is yet another example of how individuals could possibly become rich (for a short while before they expire), but only through employing posthuman neoliberal tools that alienate and isolate the self---a realization of capital is met with the eradication of the self. Thus, de Boya distances his mother and gives up on love to acquire and collect money which leaves him feeling displaced and empty. Overall, it seems like the future of the genre of the novel, especially the bildungsroman, depends on the viability of its human characters. Is it possible that the geschäftsroman will entirely substitute the bildungsroman? Or is it possible that the bildungsroman will resist this posthuman neoliberal turn? We hope it is the latter. 


\section{REFERENCES}

Asl, M. P., \& Abdullah, N. F. L. (2017). "Circulation of the Discourse of American Nationalism through Allegiance to Consumer Citizenship in Jhumpa Lahiri's The Namesake." GEMA Online ${ }^{\circledR}$ Journal of Language Studies. 17(2), 54-68.

Bakhtin, M.M. (1986). Speech Genres \& Other Late Essays. Trans. Vern W. McGee. Edited Caryl Emerson \& Michael Holquist. University of Texas.

Braidotti, R. (2013). The Posthuman. Cambridge, Polity Press.

Brown, W. (2015). Undoing the Demos: Neoliberalism's Stealth Revolution. Zone Books.

Cheney-Lippold, J. (2017). We are Data: Algorithms and the Making of our Digital Selves. New York, New York University Press.

Gilvarry, A. (2013). "'How to Get Filthy Rich in Rising Asia' by Mohsin Hamid." Review of How to get Filthy Rich in Rising Asia, Boston Globe, https://www.bostonglobe.com/arts/books/2013/03/09/book-review-how-get-filthyrich-rising-asia-mohsin-hamid/Rzr5dvZptC4c8ubR6PpIGP/story.html

Hamid, Mohsin. (2013). How to get Filthy Rich in Rising Asia. New York, Riverhead Books.

Horvat, S. (2020). "Noam Chomsky: Coronavirus - What is at stake?|DiEM25 TV." YouTube, Interview with Noam Chomsky, https://www.youtube.com/watch?v=t-N3In2rLI4.

Huehls, M, \& Smith, R. G. (2017). Neoliberalism and Contemporary Literary Culture. John Hopkins University Press.

Idrus, Mohd Muzhafar, Ruzy Suliza Hashim, \& Raihanah Mohd Mydin. (2020). "Postcolonial Civic Identity and Youth (dis)organizing Environment: A Growth into Citizenship Analysis." GEMA Online ${ }^{\circledR}$ Journal of Language Studies. 20(2), 133-147.

Lima, E. (2011). "The Uneven Development of the Bildungsroman: D'Arcy McNickle and Native American Modernity." Comparative Literature. 63(3), 291-306.

Mazzoni, G. (2017). Theory of the Novel. Harvard University Press.

Mehrvand, Ahad \& Javad Khorsandi. (2018). "Anonymous Collectivity" and "Sly Civility": Postcolonial Defiance in a Satirical Short Story by Aziz Nesin. GEMA Online ${ }^{\circledR}$ Journal of Language Studies. 18(2), 31-45.

Metcalf, S. (2017). "Neoliberalism: The Idea that Swallowed the World." The Guardian. Retrieved September 14, 2018 from www.theguardian.com/news/2017/aug/18/neoliberalism-the-idea-that-changed-theworld

Miller, L. (2013). "How to Get Filthy Rich in Rising Asia: Poor boy makes good.” Review of How to get Filthy Rich in Rising Asia, Salon. https://www.salon.com $/ 2013 / 03 / 21 /$ how to get filthy rich_in rising asia poor boy makes_good/

Moretti, F. (2000). The Way of the World. The Bildungsroman in European Culture. Verso.

Morgenstern, K. (2009). "On the Nature of the Bildungsroman." Trans. Tobias Boes. PMLA. 124, 647-59.

Mousley, A. (2016). The Posthuman. In Andrew Smith (Ed.). The Cambridge Companion to Frankenstein (pp. 158-172). Cambridge UP.

Nandi, S. (2017). Narrative Ambiguity and the Neoliberal Bildungsroman in Aravind Agida's The White Tiger. Journal of Narrative Theory. 47(2), 276-301.

Nilges, M. (2017). "Fictions of Neoliberalism: Contemporary Realism and the Temporality of Postmodernism's End." Neoliberalism and Contemporary Literary Culture. John Hopkins University Press, pp. 105-121.

---. (2015). Neoliberalism and the time of the novel. Textual Practice. 29(2), 357-377. 
Peters, M. A. (2016). Education, neoliberalism, and human Capital: homo-economicus as entrepreneur of himself. In S. Springer, K. Birch \& J. MacLeavy (Ed.). The Handbook of Neoliberalism (pp. 297-307). Routledge.

Read, J. (2006). A Genealogy of Homo-Economicus: Neoliberalism and the Production of Subjectivity. Foucault Studies. 6, 25-36.

Song, Min Hyoung. (2017). The New Materialism and Neoliberalism.Neoliberalism and Contemporary Literary Culture. John Hopkins University Press.

Thamarana, S. (2015). Origin and Development of Bildungsroman Novels in English Literature. International Journal of English Language Literature and Humanities. 3(4), 21-26.

\section{ABOUT THE AUTHORS}

Bayan AlAmmouris is a full-time lecturer of English Literature at The University of Jordan. Her research interests include Human Rights and Literature, Modern Fiction Studies, Feminist Studies, Minority Fiction, and Postcolonial Studies.

Dina Salman is an assistant professor at The University of Jordan's English Department. Her research interests include Novel and Narrative Theory, Eighteenth-Century British Literature, and Nineteenth-Century British Literature. 